\title{
The Characteristics of Literacy Management in School Literacy Movement (SLM) at Junior High School in Malang - Indonesia
}

\author{
Yuni Pantiwati ${ }^{1}$, Fendy Hardian Permana ${ }^{1}$, Tuti Kusniarti ${ }^{2}$ \& Fuad Jaya Miharja ${ }^{1}$ \\ ${ }^{1}$ Department of Biology Education, Universitas Muhammadiyah Malang, Malang, Indonesia \\ ${ }^{2}$ Department of Indonesian Language and Literature Education, Universitas Muhammadiyah Malang, Malang, \\ Indonesia \\ Correspondence: Yuni Pantiwati, Department of Biology Education, Universitas Muhammadiyah Malang, \\ Tlogomas Street No. 246 Malang, East Java, 65144, Indonesia. Tel: 62-341-464-318 E-mail: \\ yuni_pantiwati@yahoo.com
}

Received: December 13, 2019

Accepted: December 19, 2019

Online Published: March 30, 2020

doi:10.5539/ass.v16n4p15

URL: https://doi.org/10.5539/ass.v16n4p15

\begin{abstract}
This study aims to evaluate the implementation of the school literacy movement (SLM) program in junior high schools in Malang, East Java, Indonesia. The evaluation includes three stages of SLM: the stage of habituation, development, and learning. This study was an evaluative study using the CIPP model (context, input, process, and product) and used a qualitative descriptive approach. The sample unit consisted of 12 schools, with a category of nine public schools and three private schools. The schools were selected using a purposive random sampling technique. The research sample consisted of teachers, principals, and education personnel. Methods of data collection through observation, interviews, and examination of program implementation documents. Data analysis uses the Miles and Huberman model which consists of data reduction, data display, and conclusion drawing, while the formulation of strategic steps uses the calculation of internal strategic factors (IFAS) and external strategic factors (EFAS). The results showed that the implementation of new literacy at the habituation and development stage had not yet reached the learning stage. However, IFAS and EFAS values are 3.34 and 3.39 , respectively. These results indicate that the development of the literacy program still has many weaknesses $(<5.00)$ and needs intensive efforts in order to increase student literacy.
\end{abstract}

Keywords: EFAS, IFAS, literacy management, school literacy movement

\section{Introduction}

The effort to develop students' character is a manifestation of strengthening the fundamental values of education itself (Arthur \& Harrison, 2012; Durlak, Weissberg, Dymnicki, Taylor, \& Schellinger, 2011). Several studies note that there are various factors underlying the success of these efforts, such as the existence of policies (Schleicher \& Echazarra, 2016; Swain \& Cara, 2018) as well as in-depth academic studies (Young-Jones, Burt, Dixon, \& Hawthorne, 2013). In addition to these factors, the culture of literacy ecosystems was identified as a critical factor in the success of character building (Ahmadi \& Yulianto, 2017; Lewinsohn et al., 2014). Literacy studies state that the emergence of the literate ecosystem represents the growth of the values of lifelong learning in all the learning elements involved (Tabačková, 2015; Trilling \& Fadel, 2009).

Hence, several studies state that the level of student literacy in Indonesia is still below average (Kemendikbud, 2016b; Schleicher \& Echazarra, 2016). As much as 42.3\%, the literacy level of students in science, mathematics, and reading is at level 2, while those at level 5-6 are less than $1 \%$ (Schleicher, 2018). Meanwhile, the results of surveys from various international institutions such as progress in international reading literacy studies (PIRLS) and the International Association for Educational Achievement (IAEA) also show results that are not much different (Kemendikbud, 2016b). The results of the study have sufficiently provided an idea of the literacy position of Indonesian students in global competition.

Interestingly, those studies stimulate efforts to improve learning in Indonesia (Sukardjo \& Sugiyanta, 2018). It studies are turning points of learning reform based on strengthening students' literacy abilities. Several studies report that efforts to strengthen literacy are carried out at almost all levels of education, such as primary schools (Antoro, 2017; Teguh, 2013), secondary schools (Lastiningsih, Mutohir, Riyanto, \& Siswono, 2017; Noviar, 
2016; Setiyadi, 2018), to college (Kurniawan, 2016). Furthermore, these efforts are carried out in synergy not only in the realm of formal education in schools (Antoro, 2017) but also in the non-formal realm carried out by the community independently (Herdiansah \& Randi, 2016; Hou, 2014).

In its implementation, the government carried out literacy strengthening through the school literacy movement program (Kemendikbud, 2016b, 2017c). This program is a strategic step in the effort to create a school culture that is cultured in reading. The implementation of this activity uses a multidimensional approach including a process approach and learning approach (Kemendikbud, 2017a; Ministry for Education and Employment, 2014). Simultaneously, the program was also designed to actively involve the school and community components (Antoro, 2017; Suwono, 2016). However, schools are faced with differences in the characteristics of students in particular and society in general (Pradana, Fatimah, \& Rochana, 2017). In addition, the availability of resources and school culture is also a variable that influences the implementation of the literacy program. These things lead to differences in achievements and strategies undertaken by schools for the success of the program.

However, studies examining the achievements of the literacy strengthening movement and the potential for developing literacy programs based on school characteristics have not been carried out (Pradana et al., 2017; Teguh, 2013). In fact, precise and in-depth analysis is needed in evaluating the implementation of a program (Anderson, 2013; Creswell, 2014). Moreover, the program aims to change slowly a situation that is closely related to the attitudes and mindsets of a social community (Ertmer \& Newby, 2013; Winata, Cacik, \& Seftia, 2018; Wolgast, 2018). Furthermore, the analysis carried out needs to be based on various factors, internal and external, which are indicated to be able to stimulate the success of the program and minimize weaknesses and answer the challenges faced (Rahabav, 2016). This study aims to answer two big questions about how the implementation of the literacy program and an analysis of the potential for program development can be done.

\section{Method}

This qualitative descriptive study was conducted for six months. The research population consists of all junior high schools in Malang, East Java. The sample unit consisted of 12 schools, with a category of nine public schools and three private schools. The schools were selected using a purposive random sampling technique. The research sample consisted of teachers, principals, and education personnel. Considerations taken in sampling are that schools have had and run literacy programs for a minimum of five years, have facilities and infrastructure to support the literacy movement and have a school literacy team.

The data consists of primary data and secondary data. Primary data come from the respondents involved, while secondary data come from other supporting data sources such as publication documents and activity reports. Data validity was tested using source triangulation and technique triangulation. Data analysis uses the Miles and Huberman model, which consists of data reduction, data display, and conclusion drawing (Miles, Huberman, \& Saldana, 2014), while the formulation of strategic steps uses the calculation of internal strategic factors (IFAS) and external strategic factors (EFAS) (Sulaeman, Maarif, \& Affandi, 2016).

\section{Results and Discussion}

\subsection{Literacy Movement Achievements}

The literacy movement is implemented in three stages, including habituation, development, and learning (Kemendikbud, 2016b). The three stages represent the flow of movements that have been carried out at school. The results showed that the $99.1 \%$ habituation stage was carried out, while that which was not carried out was 0.9 (Table 1).

The condition of school facilities and infrastructure is also an important part of carrying out the SLM program activities (Lastiningsih et al., 2017; Ngwaru \& Opoku-Amankwa, 2010). Support for the existence of facilities and infrastructure in accordance with the provisions of the program is noteworthy (Trilling \& Fadel, 2009). The facilities and infrastructure can be in the form of adequate library space. The condition of the library must be able to attract students to continue looking for reading material for them (Ashaver \& Igyuve, 2013; Klucevsek \& Brungard, 2016). The appropriateness of the library space, the number of collections of reading materials, and the various types of interesting reading material are also of concern (Burkhardt, Kinnie, \& Cournoyer, 2008).

The availability of facilities and infrastructure owned varies, both those contained in the classroom and those located in the school environment. The existence of these supporting facilities has an impact on increasing students' interest in reading so that it indirectly provides a different learning atmosphere and teaches them as lifelong learners (Kemendikbud, 2016a).

Classrooms with reading corners are the object of monitoring and evaluation of the SLM program. The collection material in the reading corner and those variety are the objects being evaluated. Students as objects of 
the implementation of SLM programs are evaluated based on their readiness (Lastiningsih et al., 2017; Teguh, 2013). The readiness of students' attitudes and motivation towards the existence of the program. Other conditions can be evaluated on the involvement of students in classroom reading corner arrangement, as well as support to participate in including reading material contributions in the classroom reading corner (Stewart, 1995). In addition, the students, educators, and education are also important to prepare themselves. The readiness of educators and education personnel are based on leadership instructions and also their motivation for the program (Hiebert, Gallimore, \& Stigler, 2002; May, 2007). They are expected to be quite enthusiastic about the existence of the SLM program. This is driven by the spirit of increasing students' reading interest, which culminates in their academic abilities (Murray \& Harrison, 2011).

Table 1. Evaluation of the achievement of the implementation of the SLM program in the habituation stage

\begin{tabular}{|c|c|c|}
\hline No & Activities & Describe \\
\hline 1. & $\begin{array}{l}15 \text { minute reading activity: } \\
\text { Read aloud } \\
\text { Read silently } \\
\text { The } 15 \text { minute reading activity is carried out every day } \\
\text { (at the beginning, middle, or near the end of the lesson) }\end{array}$ & $\begin{array}{l}\text { The 15-minute activity, read aloud or read silently, has } \\
\text { been carried out every day at the beginning, middle, or } \\
\text { towards the end of the lesson in each class }\end{array}$ \\
\hline 2. & $\begin{array}{l}\text { Record the identity of a book that has been read in a } \\
\text { diary }\end{array}$ & $\begin{array}{l}\text { Not yet fully recorded but the record data book has been } \\
\text { prepared }\end{array}$ \\
\hline 3. & $\begin{array}{l}\text { The teachers, principals, and other education personnel } \\
\text { are involved in 15-minute activities by reading books } \\
\text { or taking part in reading silently. }\end{array}$ & $\begin{array}{l}\text { Not actively involved and become a model in 15-minute } \\
\text { reading activities }\end{array}$ \\
\hline 4. & $\begin{array}{l}\text { There is a school library or special room for storing } \\
\text { non-study books }\end{array}$ & Already in class and library \\
\hline 5. & $\begin{array}{l}\text { There is a class reading corner with a collection of } \\
\text { non-study books }\end{array}$ & Already in each class \\
\hline 6. & $\begin{array}{l}\text { There are reading campaign posters in classrooms, } \\
\text { corridors, and other school areas. }\end{array}$ & $\begin{array}{l}\text { Already in class and outside the classroom and around the } \\
\text { school environment }\end{array}$ \\
\hline 7. & There is rich text material in each class. & Already in each class \\
\hline 8. & $\begin{array}{l}\text { School gardens, canteens, and health unit facility } \\
\text { become a rich environment of literacy. }\end{array}$ & $\begin{array}{l}\text { Writing and placing posters needs to be optimized. } \\
\text { Likewise poster content needs to be adjusted to the } \\
\text { location and mission of each }\end{array}$ \\
\hline 9. & $\begin{array}{l}\text { Public involvement in the development of school } \\
\text { literacy activities }\end{array}$ & $\begin{array}{l}\text { During the training, the public engagement program began } \\
\text { to be implemented }\end{array}$ \\
\hline
\end{tabular}

The evaluation results of the habituation stage show that only one indicator has not been fully achieved while the other eight indicators are met. One indicator that has not been fulfilled is the documentation of reading titles read by students. In this case, the school has not implemented the reading recording mechanism and sources identity during the implementation of literacy habituation activities. The implementation of the SLM program emphasizes the habit of reading materials according to their interests (Klucevsek \& Brungard, 2016). The habituation process begins with reading material or non-lesson books at the beginning of each lesson every day. The reading activity for elementary school students equals is expected to become the habit of students (Zasacka, 2017). This habit will encourage students' curiosity about each of their reading material (Saito et al., 2015; Setiyadi, 2018). Reading for approximately fifteen minutes with a variety of methods is believed to arouse the students' enthusiasm and memory capacity (Lastiningsih et al., 2017; Shipstead, Lindsey, Marshall, \& Engle, 2014). The process is continued by students by revealing the reading they have read. These expressions can be either written or presented in front of the class (Teguh, 2013).

With the achievement of habituation stage indicators, the school develops literacy programs until the development stage. This activity is a follow up to the habituation stage. The evaluation results of the development stage (Table 2) shows that three indicators have been implemented while the other three indicators 
have not been implemented, among others 1) the formation of a school literacy team, 2) the variation in the collection of enrichment books are still limited, and 3) the students' responses after low reading.

Table 2. Achievement of the SLM program development stage

\begin{tabular}{|c|c|c|}
\hline No & Activities & Describe \\
\hline 1. & 15 minute reading activity & $\begin{array}{l}\text { The 15-minute activity read aloud and read silently has } \\
\text { been carried out every day at the beginning, middle, or } \\
\text { towards the end of the lesson in each class }\end{array}$ \\
\hline 2. & $\begin{array}{l}\text { There are activities to respond to enrichment books during } \\
\text { literacy lessons or hours of activities in the school library/ } \\
\text { reading corner of the class or relevant lesson hours }\end{array}$ & There are enrichment books but they have not varied \\
\hline 3. & There is a varied collection of enrichment books & There are enrichment books but they have not varied \\
\hline 4. & $\begin{array}{l}\text { There are activities to respond to reading through reading } \\
\text { aloud interactive activities, guided reading, reading } \\
\text { together, and reading independently }\end{array}$ & $\begin{array}{l}\text { Activities to respond to reading have been carried out, } \\
\text { but students have not responded optimally }\end{array}$ \\
\hline 5. & $\begin{array}{l}\text { There are activities to appreciate students' literacy } \\
\text { achievements }\end{array}$ & $\begin{array}{l}\text { There is an appreciation activity for literacy } \\
\text { achievements after coaching }\end{array}$ \\
\hline 6. & There is a school literacy team (SLT) & $\begin{array}{l}\text { SLT was formed after facilitation and assistance by the } \\
\text { service team, but it has not gone well }\end{array}$ \\
\hline
\end{tabular}

Reading habit is expected to be able to initiate students to produce productive work (Setiyadi, 2018; Tsuneyoshi, 2012). Students' productive work includes summaries of results from the reading material. Other works can also be in the form of word expressions or motivational sentences. The results are written in the student's journal about how many books have been read. The various types of books that have been read by students are also objects that are evaluated. Based on these records, it can be seen the interests and talents of students for advanced stage literacy activities in higher education how the work of students related to the SLM program is reviewed by program guidelines.

Table 3. Achievement of the SLM program learning stage

\begin{tabular}{|c|c|c|}
\hline No & Activities & Describe \\
\hline 1. & There are enrichment books that are used in learning all subjects & Not yet fully equipped \\
\hline 2. & $\begin{array}{l}\text { There is a reading strategy that is used to improve students' } \\
\text { understanding of reading in all subjects }\end{array}$ & There is a reading strategy but it is still not optimal \\
\hline 3. & $\begin{array}{l}\text { There are activities to respond to reading in the form of oral, } \\
\text { written, artistic, craft, etc. activities, in accordance with students' } \\
\text { literacy skills }\end{array}$ & Activities respond, but need to be improved \\
\hline 4. & $\begin{array}{l}\text { There are learning activities that take place in the school library, } \\
\text { reading corners, reading areas, etc. }\end{array}$ & $\begin{array}{l}\text { There are activities in the library, in the reading } \\
\text { corner, but need to be optimized }\end{array}$ \\
\hline 5. & $\begin{array}{l}\text { There are academic awards that take into account students' } \\
\text { literacy skills }\end{array}$ & $\begin{array}{l}\text { There is an award, but the quality and quantity } \\
\text { need to be improved }\end{array}$ \\
\hline 6. & $\begin{array}{l}\text { There is a school literacy team, in collaboration with public } \\
\text { elements, which organizes literacy activities at school regularly } \\
\text { and regularly }\end{array}$ & $\begin{array}{l}\text { The new SLT was formed so that it hasn't worked } \\
\text { properly. }\end{array}$ \\
\hline
\end{tabular}

Based on a program that has been running for a certain period of time, the impact that appears can be evaluated. The impact that can be evaluated in this SLM program is the short-term impact (Bakar, Yun, Keow, \& Li, 2014; Short, 2009). These impacts are evaluated based on participants' activities after the program has been running at an early stage (Lewis \& Wray, 2001). These results indicate that students' literacy is influenced by effective learning groups, general classroom behavior, and motivation that grows during the process (Lewis \& Wray, 2001; May, 2007). 


\subsection{Potencies of SLM Development Programme}

Significant achievements in the literacy movement can be used as a basis for sustainable SLM development. The results of the SWOT analysis show the achievements and the possibility of developing programs that can be done (Helms \& Nixon, 2010). Strength elements of human resources, facilities, abilities, school conditions, and strategic efforts that have been made. On the other hand, internal weaknesses that become a minimal factor, such as the availability of material, student readiness, teacher competence, and development strategies in supporting the development of SLM can be identified and anticipated (Agarwal, Grassl, \& Pahl, 2012). On the other side, the external factor is an opportunity to consider the existence of cooperation, financial assistance, and government policies that allow it to support the development of SLM. Likewise, threats can arise from the surrounding environment that can hamper the program (Agarwal et al., 2012). The SWOT analysis results are then summarized in Table 4 and Table 5.

Table 4. Internal strategic factor analysis model (IFAS)

\begin{tabular}{|c|c|c|c|c|}
\hline No & Strategic Factors & Weight & Rating & $\begin{array}{l}\text { Weight } \mathrm{x} \\
\text { Rating }\end{array}$ \\
\hline \multicolumn{5}{|c|}{ Strength $(\mathrm{S})$} \\
\hline 1 & Students read for 15 minutes at the beginning of learning & 0.03 & 4 & 0.13 \\
\hline 2 & Students like to read science & 0.03 & 4 & 0.12 \\
\hline 3 & Students read according to their interests & 0.03 & 4 & 0.10 \\
\hline 4 & Special reading activities for science & 0.03 & 4 & 0.11 \\
\hline 5 & School becomes a reference school & 0.02 & 4 & 0.09 \\
\hline 6 & Student handbook availability & 0.02 & 4 & 0.10 \\
\hline 7 & Students retell the reading content & 0.02 & 4 & 0.10 \\
\hline 8 & First hour teacher to be in charge of the activities & 0.02 & 4 & 0.09 \\
\hline 9 & Showcase of journalistic tasks & 0.01 & 3 & 0.04 \\
\hline 10 & Having a variety reading corner & 0.03 & 4 & 0.10 \\
\hline 11 & Literacy poster & 0.02 & 4 & 0.10 \\
\hline 12 & Students listening awareness & 0.03 & 4 & 0.12 \\
\hline 13 & Commenting each others & 0.03 & 4 & 0.11 \\
\hline 14 & Having a portofolio & 0.02 & 3 & 0.05 \\
\hline 15 & Students product bazaar & 0.02 & 3 & 0.05 \\
\hline 16 & Structural school literacy team & 0.02 & 4 & 0.08 \\
\hline 17 & Students carrying textbooks also read non-textbooks & 0.02 & 3 & 0.05 \\
\hline 18 & Making a concept map & 0.02 & 4 & 0.09 \\
\hline 19 & Students mind mapping of science subjects & 0.03 & 4 & 0.11 \\
\hline 20 & Students are accustomed to solving problems using learning variety resources & 0.03 & 4 & 0.11 \\
\hline 21 & Students are skilled at operating the internet & 0.02 & 3 & 0.05 \\
\hline 22 & Collection of reference books are varies & 0.02 & 3 & 0.05 \\
\hline 23 & Students are accustomed to reading silently & 0.02 & 3 & 0.05 \\
\hline 24 & Use strategies to help understand the text & 0.02 & 4 & 0.08 \\
\hline 25 & $\begin{array}{l}\text { Planning. implementation and assessment of the literacy and SLM programs } \\
\text { are underway }\end{array}$ & 0.03 & 4 & 0.11 \\
\hline 26 & The habitual SLM program is held twice a week & 0.02 & 3 & 0.06 \\
\hline 27 & Homeroom teacher conducts SLM assessment & 0.03 & 4 & 0.11 \\
\hline 28 & The response writing tool uses graphic organizers & 0.02 & 4 & 0.08 \\
\hline 29 & The school gives a literacy certificate as a condition for taking report cards & 0.02 & 3 & 0.05 \\
\hline 30 & School policies support the SLM program & 0.02 & 3 & 0.05 \\
\hline \multicolumn{2}{|c|}{ Sub-Total } & 0.68 & & 2.54 \\
\hline
\end{tabular}




\begin{tabular}{|c|c|c|c|c|}
\hline No & Strategic Factors & Weight & Rating & $\begin{array}{c}\text { Weight } \mathrm{x} \\
\text { Rating }\end{array}$ \\
\hline \multicolumn{5}{|c|}{ Weakness (W) } \\
\hline 1 & Students are lazy to read & 0.04 & 3 & 0.11 \\
\hline 2 & The reading material is not focused on science & 0.04 & 3 & 0.11 \\
\hline 3 & The number of posters is still limited & 0.02 & 2 & 0.04 \\
\hline 4 & Students are still weak in giving solutions to problems from reading & 0.03 & 3 & 0.09 \\
\hline 5 & Not appropriate portfolios & 0.02 & 2 & 0.04 \\
\hline 6 & The literacy culture of the SLM program has not yet been realized & 0.04 & 3 & 0.11 \\
\hline 7 & There is no mobile library around the school & 0.04 & 3 & 0.11 \\
\hline 8 & Granting literacy awards has not been periodic & 0.02 & 2 & 0.04 \\
\hline 9 & Non-academic assessment has not been done & 0.03 & 2 & 0.06 \\
\hline 10 & The literacy achievement assessment is not in accordance with SLM guidelines & 0.02 & 2 & 0.04 \\
\hline 11 & The implementation of SLM has not yet fully met the established standards & 0.02 & 2 & 0.05 \\
\hline 12 & The teacher hasn't read aloud yet & 0.02 & 1 & 0.02 \\
\hline \multicolumn{2}{|c|}{ Sub-Total } & 0.33 & & 0.80 \\
\hline \multicolumn{2}{|c|}{ Total } & 1.000 & & 3.34 \\
\hline
\end{tabular}

Table 5. External strategic factor analysis model (EFAS)

\begin{tabular}{|c|c|c|c|c|}
\hline No & Strategic Factors & Weight & Rating & $\begin{array}{c}\text { Weight } x \\
\text { Rating }\end{array}$ \\
\hline \multicolumn{5}{|c|}{ Opportunity (O) } \\
\hline 1 & Parental support & 0.20 & 4 & 0.79 \\
\hline 2 & The entire school literacy team is striving to achieve SLM targets and goals & 0.10 & 4 & 0.41 \\
\hline 3 & The school literacy team is committed to running the SLM program & 0.11 & 4 & 0.44 \\
\hline 4 & Funding from the government & 0.18 & 3 & 0.55 \\
\hline 5 & Literacy field visit & 0.14 & 4 & 0.56 \\
\hline \multirow[t]{2}{*}{6} & Governmental support & 0.15 & 3 & 0.46 \\
\hline & Sub-Total & 0.89 & & 3.21 \\
\hline \multicolumn{5}{|c|}{ Threat (T) } \\
\hline 1 & Changes in the industrial world that have an impact on literacy & 0.03 & 2 & 0.06 \\
\hline 2 & Technological developments that reduce students' interest in reading & 0.01 & 2 & 0.02 \\
\hline 3 & Inappropriate teacher motivation and workload & 0.02 & 1 & 0.02 \\
\hline 4 & Vandalism behavior towards literacy facilities & 0.03 & 2 & 0.06 \\
\hline \multirow[t]{3}{*}{5} & Changes in educational policies & 0.03 & 1 & 0.03 \\
\hline & Sub-Total & 0.11 & & 0.18 \\
\hline & Total & 1.00 & & 3.39 \\
\hline
\end{tabular}

Table 4 and Table 5 shows strength scores 0.68 , weakness 0.33 , opportunity 0.89 , and threats 0.11 . It is known that the strength value is above the weakness score $(+) 1.96$, and the opportunity score is above the threat value with a difference $(+)$ 1.47. These results indicate that these factors can be illustrated in the SWOT diagram (Figure 1).

Figure 1 shows that the implementation of the SLM program is strong enough and has a great opportunity to be developed. The recommended strategy is a progressive work plan, increase business, and achieve optimal progress. GLS can be developed both in number and type (Helms \& Nixon, 2010; Zasacka, 2017). This situation 
is a very favorable situation. The government has opportunities and flexibility so that they can take advantage of existing opportunities (Kemendikbud, 2017b). The strategy that must be applied in this condition is to support an aggressive growth policy (Beverton \& Sewell, 2002; Ministry for Education and Employment, 2014).

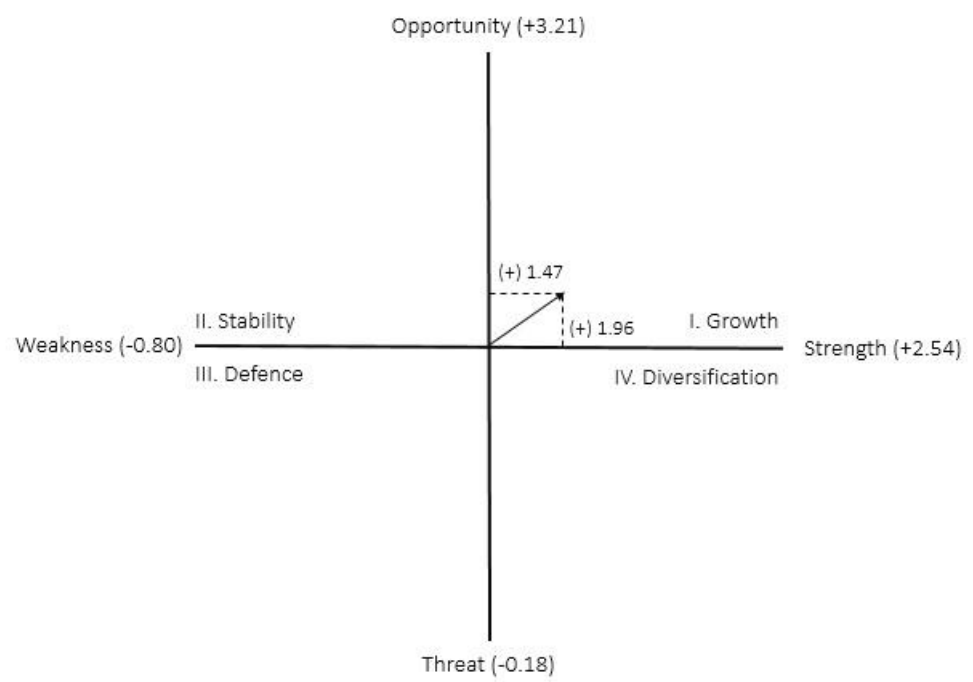

\section{Conclusion}

Figure 1. Analysis of the potential implementation of the SLM program

The results showed that the implementation of the literacy program had reached the stage of habituation and development. However, the calculation of internal strategic factors (3.34) and external factors (3.39) indicated the implementation of the program were still many weaknesses. Thus, intensive efforts need to be made in order to improve student literacy skills.

\section{Acknowledgments}

This research was carried out with the support of internal funding through the research scheme of the Directorate of Research and Community Service/Direktorat Penelitian dan Pengabdian kepada Masyarakat (DPPM), University of Muhammadiyah Malang.

\section{References}

Agarwal, R., Grassl, W., \& Pahl, J. (2012). Meta-SWOT: Introducing a new strategic planning tool. Journal of Business Strategy, 33(2), 12-21. https://doi.org/10.1108/02756661211206708

Ahmadi, A., \& Yulianto, B. (2017). Descriptive-analytical studies of literacy movement in Indonesia, 2003-2017. International Journal of Humanities and Cultural Studies, 4(3), 16-24. Retrieved from http://www.ijhcs.com/index.php/ijhcs/index

Anderson, A. (2013). Learning to be resilient global citizens for a sustainable world. Retrieved from https://unesdoc.unesco.org/ark:/48223/pf0000225940

Antoro, B. (2017). Gerakan literasi sekolah. Dari pucuk hingga akar. Jakarta: Kementerian Pendidikan dan Kebudayaan. https://doi.org/10.1017/S0033291700036606

Arthur, J., \& Harrison, T. (2012). Exploring good character and citizenship in England. Asia Pacific Journal of Education, 32(4), 489-497. https://doi.org/10.1080/02188791.2012.741097

Ashaver, D., \& Igyuve, S. M. (2013). The use of audio-visual materials in the teaching and learning processes in colleges of education in Benue State-Nigeria. IOSR Journal of Research \& Method in Education (IOSRJRME), 1(6), 44-55. https://doi.org/10.9790/7388-0164455

Bakar, Z. A., Yun, L. M., Keow, N. S., \& Li, T. H. (2014). Goal-setting learning principles : a lesson from practitioner. Journal of Education and Learning, 8(1), 41-50. https://doi.org/10.11591/edulearn.v8i1.204

Beverton, S., \& Sewell, G. (2002). Implementing whole school literacy policies. Education 3-13, 30(1), 24-29. https://doi.org/10.1080/03004270285200061

Burkhardt, J. M., Kinnie, J., \& Cournoyer, C. M. (2008). Information literacy successes compared: Online vs.

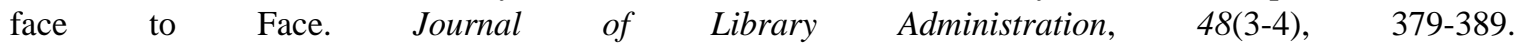


https://doi.org/10.1080/01930820802289425

Creswell, J. W. (2014). Research design. Qualitative, quantitative, and mixed methods approaches (3rd ed). Sage Publisher. Retrieved from http://books.google.com/books?id=bttwENORfhgC\&pgis=1

Durlak, J. A., Weissberg, R. P., Dymnicki, A. B., Taylor, R. D., \& Schellinger, K. B. (2011). The impact of enhancing students' social and emotional learning: A meta-analysis of school-based universal interventions. Child Development, 82(1), 405-432. https://doi.org/10.1111/j.1467-8624.2010.01564.x

Ertmer, P. A., \& Newby, T. J. (2013). Behaviorism, cognitivism, constructivism: Comparing critical features from an instructional design perspective. Performance Improvement Quarterly, 24(3), 55-76. https://doi.org/10.1002/piq.21143

Helms, M. M., \& Nixon, J. (2010). Exploring SWOT analysis - where are we now? A review of academic research from the last decade. Journal of Strategy and Management, 3(3), 215-251. https://doi.org/10.1108/17554251011064837

Herdiansah, A. G., \& Randi, R. (2016). Peran organisasi masyarakat (Ormas) dan lembaga swadaya masyarakat (LSM) dalam menopang pembangunan di Indonesia. Sosioglobal: Jurnal Pemikiran Dan Penelitian Sosiologi, 1(1), 49-67. https://doi.org/10.24198/jsg.v1i1.11185

Hiebert, J., Gallimore, R., \& Stigler, J. W. (2002). A knowledge base for the teaching profession: what would it look like and how can we get one? Educational Researcher, 31(5), 3-15. https://doi.org/10.1111/j.1540-8183.1994.tb00887.x

Hou, S.-I. (2014). Integrating problem-based learning with community-engaged learning in teaching program development and implementation. Universal Journal of Educational Research, 2(1), 1-9. https://doi.org/10.13189/ujer.2014.020101

Kemendikbud, K. (2016a). Panduan gerakan literasi sekolah di sekolah dasar. Jakarta. Retrieved from http://repositori.kemdikbud.go.id/40/1/Panduan-Gerakan-Literasi-Sekolah-di-SD.pdf

Kemendikbud, K. (2016b). Pedoman pelaksanaan gerakan nasional literasi bangsa. Jakarta. Retrieved from https://gln.kemdikbud.go.id/glnsite/wp-content/uploads/2017/09/Pedoman-GLNB-2016-2019.pdf

Kemendikbud, K. (2017a). Infografis gerakan penguatan pendidikan karakter (PPK). Indonesian Ministry of Education and Culture. Retrieved from cerdasberkarakter.kemendikbud.go.id

Kemendikbud, K. (2017b). Panduan gerakan literasi nasional. Jakarta. Retrieved from http://gln.kemdikbud.go.id/glnsite/wp-content/uploads/2017/08/panduan-gln.pdf

Kemendikbud, K. (2017c). Panduan penilaian penguatan pendidikan karakter. Jakarta. Retrieved from http://repositori.kemdikbud.go.id/10119/1/1_final_Panduan_Penilaian_0k.pdf

Klucevsek, K. M., \& Brungard, A. B. (2016). Information literacy in science writing: How students find, identify, and use scientific literature. International Journal of Science Education, 38(17), 2573-2595. https://doi.org/10.1080/09500693.2016.1253120

Kurniawan, R. Y. (2016). Identifikasi permasalahan pendidikan di Indonesia untuk meningkatkan mutu dan profesionalisme guru. In Konvensi Nasional Pendidikan Indonesia (pp. 1415-1420). Jakarta: Universitas Negeri Jakarta.

Lastiningsih, N., Mutohir, T. C., Riyanto, Y., \& Siswono, T. Y. E. (2017). Management of the school literacy movement (SLM) programme in indonesian junior secondary schools. World Transactions on Engineering and Technology Education, 15(4), 384-389. Retrieved from http://www.wiete.com.au/journals/WTE\&TE/Pages/Vol.15,No.4(2017)/13-Lastiningsih-N.pdf

Lewinsohn, T. M., Attayde, J. L., Fonseca, C. R., Ganade, G., Jorge, L. R., Kollmann, J., ...Weisse, W. W. (2014). Ecological literacy and beyond : Problem-based learning for future professionals. Royal Swedish Academy of Sciences, Juni, 1-9. https://doi.org/10.1007/s13280-014-0539-2

Lewis, M., \& Wray, D. (2001). Implementing effective literacy initiatives in the secondary school. Educational Studies, 27(1), 44-54. https://doi.org/10.1080/03055690020002125

May, S. (2007). Sustaining effective literacy practices over time in secondary schools: School organisational and change issues. Language and Education, 21(5), 387-405. https://doi.org/10.2167/le799.0

Miles, M. B., Huberman, A. M., \& Saldana, J. (2014). Chapter 5: Designing matrix and network displays. Qualitative Data Analysis A Methods Sourcebook (3rd ed.). Los Angeles: Sage Publisher. 
https://doi.org/10.1136/ebnurs.2011.100352

Ministry for Education and Employment. (2014). A national literacy strategy for all in Malta and Gozo 2014-2019. Malta. Retrieved from https://education.gov.mt/en/Documents/Literacy/ENGLISH.pdf

Murray, E., \& Harrison, L. J. (2011). The influence of being ready to learn on children's early school literacy and $\begin{array}{llll}\text { numeracy achievement. } & \text { Educational }\end{array}$ https://doi.org/10.1080/01443410.2011.573771

Ngwaru, J. M., \& Opoku-Amankwa, K. (2010). Home and school literacy practices in Africa: Listening to inner voices. Language and Education, 24(4), 295-307. https://doi.org/10.1080/09500781003678985

Noviar, D. (2016). Developing android-based mobile biology encyclopedia of the core material of pteridophyta for implementing curriculum 2013. Cakrawala Pendidikan, XXXV(2), 198-207. Retrieved from https://media.neliti.com/media/publications/85070-none-84a75287.pdf

Pradana, B. H., Fatimah, N., \& Rochana, T. (2017). Pelaksanaan gerakan literasi sekolah sebagai upaya membentuk habitus literasi siswa di SMA Negeri 4 Magelang. Solidarity, 6(2), 167-179. Retrieved from https://journal.unnes.ac.id/sju/index.php/solidarity/article/view/19560

Rahabav, P. (2016). The effectiveness of academic supervision for teachers. Journal of Education and Practice, 7(9), 47-55. Retrieved from https://files.eric.ed.gov/fulltext/EJ1095817.pdf

Saito, E., Watanabe, M., Gillies, R., Someya, I., Nagashima, T., Sato, M., \& Murase, M. (2015). School reform for positive behaviour support through collaborative learning: Utilising lesson study for a learning community. Cambridge Journal of Education, 45(4), 1-30. https://doi.org/10.1080/0305764X.2014.988684

Schleicher, A. (2018). Pisa 2015 result in focus. https://doi.org/10.1787/9789264266490-en

Schleicher, A., \& Echazarra, A. (2016). Country note - Program for international student assessment (PISA) result from PISA 2015. Retrieved from https://www.oecd.org/pisa/PISA-2015-Indonesia.pdf

Setiyadi, D. B. P. (2018). E-literary texts: Reading materials for school literacy movement. In The 1st International Seminar on Language, Literature, and Education, KnE Social Sciences (Vol. 2018, pp. 538-545). https://doi.org/10.18502/kss.v3i9.2716

Shipstead, Z., Lindsey, D. R. B., Marshall, R. L., \& Engle, R. W. (2014). The mechanisms of working memory capacity: Primary memory, secondary memory, and attention control. Journal of Memory and Language, 72(1), 116-141. https://doi.org/10.1016/j.jml.2014.01.004

Short, P. C. (2009). Responsible environmental action: Its role and status in environmental education and environmental quality. The Journal of Environmental Education, 41(1), 7-21. https://doi.org/10.1080/00958960903206781

Stewart, J. P. (1995). Home Environments and Parental Support for Literacy: Children's Perceptions and School Literacy Achievement. Early Education and Development, 6(2), 97-125. https://doi.org/10.1207/s15566935eed0602_1

Sukardjo, M., \& Sugiyanta, L. (2018). Analisis strategi pembelajaran matematika kurikulum 2013 dalam rangka meningkatkan nilai PISA matematika. JKPP: Jurnal Kesejahteraan Keluarga Dan Pendidikan, 5(1), 42-64. https://doi.org/10.21009/JKKP.051.05

Sulaeman, S., Maarif, M. S., \& Affandi, M. J. (2016). Analysis of lecturer strategic planning in improving competiveness in University of 45 Mataram. International Journal of Scientific and Research Publication, 6(7), 645-651. Retrieved from http://www.ijsrp.org/research-paper-0716/ijsrp-p5591.pdf

Suwono, H. (2016). School literary movement in Indonesia: Challenges for scientific literacy. Paper Presented at International Conference on Education, 309-317. Retrieved from http://pasca.um.ac.id/conferences/index.php/ice/article/view/44

Swain, J., \& Cara, O. (2018). The role of family literacy classes in demystifying school literacies and developing closer parent-school relations. Cambridge Journal of Education, 3577, 1-21. https://doi.org/10.1080/0305764X.2018.1461809

Tabačková, Z. (2015). Outside the classroom thinking inside the classroom walls: Enhancing students`critical thinking through reading literary texts. In Procedia - Social and Behavioral Sciences (Vol. 186, pp. 726-731). https://doi.org/10.1016/j.sbspro.2015.04.042

Teguh, M. (2013). Gerakan literasi sekolah dasar. In Aktualisasi Kurikulum 2013 di Sekolah Dasar Melalui 
Gerakan Literasi Sekolah untuk Menyiapkan Generasi unggul dan Berbudi Pekerti (pp. 18-26). Retrieved from http://pgsd.umk.ac.id/files/prosiding/2017/3 Mulyo Teguh.pdf

Trilling, B., \& Fadel, C. (2009). 21st Century skills: Learning for life in our times. 21St Century Skill. Jossey-Bass. Retrieved from https://epdf.pub/21st-century-skills-learning-for-life-in-our-times.html

Tsuneyoshi, R. (2012). The world of TOKKATSU: The Japanese approach to whole child education. Tokyo. Retrieved from http://www.p.u-tokyo.ac.jp/ tsunelab/tokkatsu/cms/wp-content/uploads/2016/03/the_worl d_of_tokkatsu.pdf

Winata, A., Cacik, S., \& Seftia, I. (2018). Kemampuan awal literasi sains peserta didik kelas V SDN Sidorejo 1 Tuban pada materi daur air. JTIEE, 2(1), 58-64. https://doi.org/10.30587/jtiee.v2i1.356

Wolgast, A. (2018). School students' beliefs about abilities and perspective - taking over time. Large-Scale Assessments in Education, 6(12), 1-22. https://doi.org/10.1186/s40536-018-0065-y

Young-Jones, A. D., Burt, T. D., Dixon, S., \& Hawthorne, M. J. (2013). Academic advising: does it really impact student success? Quality Assurance in Education, 21(1), 7-19. https://doi.org/10.1108/09684881311293034

Zasacka, Z. (2017). Screen-based reading practices - results of the Study on children's and adolescents' reading habits and attitudes. Edukacja, 99-114. https://doi.org/10.24131/3724.170507

\section{Copyrights}

Copyright for this article is retained by the author(s), with first publication rights granted to the journal.

This is an open-access article distributed under the terms and conditions of the Creative Commons Attribution license (http://creativecommons.org/licenses/by/4.0/). 